\title{
Foreign Ownership Shares and Trade Propensity in Indonesian Edible Oil, Vegetable and Animal Fats Industry
}

\author{
Dahlia Nauly \\ Universitas Muhammadiyah Jakarta, Indonesia \\ E-mail: dahlia.nauly@umj.ac.id
}

JEL Classification:
F10
F23
L66
Received: 30 Novenber 2020
$1^{\text {st }}$ Revision: 30 January 2021
$2^{\text {nd }}$ Revision: 11 April 2021
Accepted: 07 May 2021

JEL Classification:

\begin{abstract}
Presidential Regulation (Perpres) No 44/2016 states that in the vegetable and animal crude oil industry, copra industry, coconut oil industry, palm oil industry, foreign ownership is limited at a maximum of 95 percent. These industries are included in the edible oil, vegetable and animal fats industry (ISIC 104). This study analyzes the effect of foreign ownership share on the trade propensity in the edible oil, vegetable and animal fats industry in Indonesia using the Tobit model. The data used are the cross-section data from 2015 Annual Survey of the Manufacturing industry from Statistics Indonesia. The results show that firms with foreign ownership share of more than 95 percent have the same export propensity with foreign ownership of between 50 and 95 percent. However, the import propensity of firms with foreign ownership between 50 and 95 percent is the lowest compared to other ownership. The government should continue to restrict foreign ownerhip shares at the maximum of 95 percent in this industry.
\end{abstract}

\section{Keywords:}

export, foreign ownership, import, tobit model

How to Cite:

Nauly, D. (2022). Foreign Ownership Shares and Trade Propensity in Indonesian Edible Oil, Vegetable and Animal Fats Industry. Signifikan: Jurnal Ilmu Ekonomi, 11(1), 95-106. https://doi.org/10.15408/sjie.v11i1.18408. 


\section{INTRODUCTION}

One of the goals in the trade sector is increasing the export value-added of non-oil and gas products. The processed food sector is one of the main product of Indonesia's non-oil and gas exports (Hasni, 2018). Increasing exports can be done by inviting foreign investors in the form of foreign direct investment. Safitriani (2014) reveals that foreign direct investment in the long term will increase export value.

Foreign-owned firms can overcome the entry barriers to foreign markets. Foreign capital from developed countries has the opportunity to apply more advanced technology in the firms and use it to create new competitive products (Golikova \& Kuznetsov, 2016). Technology acquisition from developed countries led to innovation and learning processes in developing countries which were the main source of export excellence at the firm level (Belitz \& Mölders, 2016). Foreign firms have a faster technology transfer rate and increase incentives to adopt technology (Boddin et al., 2017). Technological innovations positively affect export intensity (Radicic \& Djalilov, 2019). Absorptive capacity is vital in capturing positive spillovers as firms build competency by accumulating their own know-how and improving their ability to capture better external technologies (M. Kim \& Choi, 2019). The exporters differ from non-exporters in terms of their firms' and owners' characteristics, their perceptions toward export barriers, their participation in their national government's export assistance program and network relationships (Revindo et al., 2019)

Knowledge transfers stemming from the transfer of managers from the parent to foreign affiliates (Cho, 2018). Apart from that, foreign firms also have international trade networks (Ramstetter, 1999). This happened because lower international trade transaction costs incurred by foreign firms when trading. Foreign direct investment also has a positive and significant effect on exports (Mijiyawa, 2016).

Foreign ownership can also increase imports of raw materials. Imports of raw materials occur when local raw materials are unable to meet the needs of foreign firms in terms of quality and quantity (Nauly et al., 2020). The existence of foreign capital is still a matter of debate in Indonesia. Foreign capital restrictions are still being implemented to protect domestic firms. One of that is Presidential Regulation (Perpres) No. 44/2016 which states that in the vegetable and animal crude oil industry, copra industry, coconut oil industry and palm oil industry, the maximum foreign ownership is 95 percent. These industries are included in the edible oil, vegetable and animal fats industry. For this reason, it is interesting to analyze the impact of the foreign ownership shares on the export propensity of firms in the industry.

Research on the effect of the foreign ownership shares on firm exports has been conducted before. Ramstetter \& Nguyen (2016) have proven that in Vietnam, wholly foreign-owned firms tend to export more than joint venture firms and the government. Ramstetter (2018) stated the same result on industries in Thailand which showed that the export propensity would be higher for firms that were wholly foreign owned. Bykova $\&$ Lopez-Iturriaga (2018) support positive impact of foreign ownership on the link between exports and firms' performance in Russian manufacturing companies. Therefore of the 
sign of the relationship, the evidence clearly points to the existence of an influence of ownership concentration on a firm's export propensity (Miravitlles et al., 2018). In addition, Charoenrat \& Amornkitvikai (2021) have proven that foreign direct investment significantly and positively influence Chinese manufacturing firms' export intensity.

Research on the effect of the foreign ownership shares on trade propensity in manufacturing firms has also been conducted in Indonesia. Ramstetter (1999) shows that Indonesian manufacturing firms with a large percentage of foreign capital will have a high export propensity, but this is not directly proportional to the import propensity. Sjöholm (2003) concluded that foreign ownership in firms increases the possibility for firms to export. This is because foreign firms have networks, especially with the countries of origin of the foreign capital.

In the food and beverage industry, the presence of foreign ownership increases the chances of a firm to export 3.67 times compared to firms without foreign capital (Rifin 2017). Nauly et al. (2020) have also conducted research on the Indonesian food industry and concluded that firms with foreign ownership have propensity to export and import, but the foreign ownership shares has no effect on export propensity.

This study aims to evaluate government policies on Indonesian edible oil, vegetable and animal fats industry related to restrictions on foreign ownership. This industry is chosen since these industries have significant contribution to Indonesian economy especially for the palm oil industry.

Previous study emphasizes on the importance of foreign ownership to export and import propensity at the aggregate level. Most studies focus on manufacturing or food industry level, meanwhile this research focuses on the edible oil, vegetable and animal fats industry. However, there is less empirical work that provides evidence on dissagregate level. The contribution of this paper is to bridge the gap by providing evidence on foreign ownership share to trade propensity. Articles on the edible oil, vegetable and animal fats industry in the firm level mostly in the palm oil sector discussing on efficiency ((Stephanie et al., 2018)

The paper is organized as follows: Section 2 describes the methods. Section 3 investigates the effect of foreign ownership shares on trade propensity with the characteristics of firm in the industry. Section 4 concludes.

\section{METHODS}

This study utilizes the 2015 Annual Manufacturing Industry Survey data from the Statistics Indonesia. This data is a cross section data. The 2015 data was used since it is the recent data available. The annual manufacturing industry survey data is often used to analyze the performance of Indonesian industry, such as that conducted by Blomström \& Sjöholm (1999), Hill (1990b, 1990a), Sjöholm (2003), Ramstetter (1999), Takii \& Ramstetter (2005), Takii (2004, 2005) and Nauly et al. (2020). This data is firm level data in the manufacturing industry which has more than 20 labor.

The industry focused in this research is the edible oil, vegetable and animal fats industry which is included in the International Standard Industrial Classification 104 
(ISIC 104). There are 910 firms in the 2015 Annual Survey of the Manufacturing Industry. After filtering the data based on the availability of value of capital and raw materials data, only 372 firms were utilized in the analysis.

Before analyzing the effect of foreign ownership share on the trade propensity, identification of the factors that influence the trade propensity was conducted. Trade propensity is the trend in exports of output and imports of raw materials so that both are used as dependent variables. The export propensity is indicated by the export ratio, which is the export value divided by the total output value produced by a firm. Meanwhile, the import propensity is indicated by the ratio of raw material imports, which is the value of imports of raw materials divided by the value of raw materials used by firms.

This study uses capital intensity, skilled labor intensity, productivity, the export and import propensity and the dummy variable of foreign ownership shares as independent variables. Capital intensity is the ratio of fixed capital divided by the number of workers. The capital/labor ratio is included in the model because it can describe the characteristics of the industry as well as the comparative advantage of the country, especially in developing countries where labor is relatively cheap compared to capital. A small capital-labor ratio indicates that more labor is used because it is relatively cheaper compared to capital. A small capital-labor ratio in an industry indicates that the firm is producing labor-intensive products. This industry has a comparative advantage and can compete with foreign firms in the international market because it relies on cheap labor (Ramstetter, 1999). Jongwanich \& Kohpaiboon (2008) and Amornkitvikai et al. (2012) found a negative effect between the capital-labor ratio and export participation for Thai manufacturing firms. Meanwhile, Athukorala et al. (1995) found that the capital intensity variable had a significant positive effect on firms' export decisions. In addition, Kokko et al. (2001) stated that there was no significant effect between the two variables.

Skilled labor is also a factor affecting trade propensity. In this study, the intensity of skilled labor is the ratio of the number of non-production workers to the total number of workers. Ramstetter (1999) shows that the intensity of skilled labor has a negative effect on export propensity. Meanwhile Dueńas-Caparas (2006) and Roper \& Love (2002) show that skilled labor has a positive influence on a firm's export decisions.

Labor productivity used in this research is the ratio of value added to the number of workers. Productivity is thought to have a positive effect on the decision to export. Firms with high productivity, export more than those with low productivity (Roberts \& Tybout, 1997).

The variable ratio of export to output and ratio import of raw materials at the industrial level is used to describe the specific effects of the industry. Ramstetter (1999) argues that a firm has a high propensity to export in industries that tend to export and vice versa. Likewise on the import side, firms in industries that tend to import will have a tendency to import as well 
The foreign ownership variable share uses a dummy variable for various groups of foreign capital ownership. Firm ownership is divided into four groups, namely firms that do not have foreign capital, firms with foreign ownership shares less than 50 percent (minority foreign ownership), firms with foreign ownership shares between 50 to 95 percent (majority foreign ownership) and firms with foreign ownership more than 95 percent. Domestic firms are used as the base. If the coefficient of the dummy variable in a group of foreign ownership shows a positive sign, it can be interpreted that foreign-owned firms in that portion have a greater tendency to export or import than domestic firms. Based on the factors that are thought to influence trade propensity (exports and imports), the variables used in the equation are as follows:

$$
\begin{aligned}
& (X / O)_{i j}=f\left((X / O)_{j},(E S / E)_{i j},(K / E)_{i j}, P T V_{i j}, D_{050}, D_{5095}, D_{95100}\right. \\
& (M / R)_{i j}=f\left((M / R)_{j},(E S / E)_{i j},(K / E)_{i j}, P T V_{i j}, D_{050}, D_{5095}, D_{95100}\right.
\end{aligned}
$$

Where:

$$
\begin{array}{ll}
\mathrm{X} & =\text { exports (thousand rupiah) } \\
\mathrm{O} & =\text { output (thousand rupiah) } \\
\mathrm{M} & =\text { imports of raw materials (thousand rupiah) } \\
\mathrm{R} & =\text { raw materials (thousand rupiah) } \\
\mathrm{K} & =\text { fixed capital (thousand rupiah) } \\
\mathrm{E} & =\text { labor (people) } \\
\mathrm{ES} & =\text { non-production labor (people) } \\
\mathrm{PTV} & =\text { productivity (thousand rupiah) } \\
\mathrm{D} 050 & =\text { dummy variable }(1=\text { foreign ownership share is greater than } 0 \% \text { to less } \\
& \text { than } 50 \%) \\
\mathrm{D} 5095 & =\text { dummy variable }(1=\text { foreign ownership share } 50 \% \text { to } 95 \%) \\
\mathrm{D} 95100 & =\text { dummy variable }(1=\text { foreign ownership share is greater than } 95 \%) \\
\mathrm{i} & =\text { firm } \mathrm{i} \\
\mathrm{j} & =\text { sub-industrial group } \mathrm{j}
\end{array}
$$

The equation is estimated using the Tobit model. This model is used because the dependent variable is limited in which the value of the export and import ratio is limited to range from 0 to 1 . Meanwhile using common regression analysis, the dependent predicted variable can be in the value of less than 0 or more than one. The zero number in the export propensity equation shows the firm does not export and the number one shows that the firm exports all the output it produces. Whereas in the import propensity equation, the zero number indicates that the firm does not import raw materials and the number one means the firm imports all the raw materials. The independent variable is converted into a logarithmic form to minimize the potential for heteroscedasticity (Kim \& Park 2011). The dependent variable still uses its original form to maintain the 
characteristics of the Tobit model that limit the dependent variable. Export propensity of industry, import propensity of industry and the intensity of skilled labor (the ratio of non-production labor to total labor) have zero values on several observations. Therefore, these variables were redefined by adding one from the original value to facilitate the use of the specifications used.

Estimation using the Tobit model has a weakness. It cannot be performed statistical tests related to heteroscedasticity. To overcome this, Ramstetter (1999) estimates using weighted and non-weighted. A smaller standard error on the weighted regression results indicates that heteroscedasticity is a problem in the unweighted regression results. The regression results shown are weighted regression results.

\section{RESULT AND DISCUSSION}

The sample description used in this study can be seen in Table 1. The table shows that 15 percent of firms in the industry doing export, 58.93 percent of export firms are domestic firms. Additionaly firms that doing import are 2.96 percent and 54.55 percent are foreign firms. This indicate that the majority of firms conducting export and import are domestics firms. Meanwhile for domestic and foreign own firms, majority of the firms do not conduct export or import.

Table 1. Number of Samples

\begin{tabular}{lccccc}
\hline \multicolumn{1}{c}{ Foreign Ownership } & Export & Import & $\begin{array}{c}\text { Export and } \\
\text { Import }\end{array}$ & $\begin{array}{c}\text { Non Export } \\
\text { Import }\end{array}$ & Total \\
\hline $0 \%$ (domestic) & 30 & 2 & 3 & 263 & 298 \\
$0 \%<$ foreign $<50 \%$ & 2 & 1 & 0 & 8 & 11 \\
$50 \% \leq$ foreign $\leq 95 \%$ & 11 & 0 & 0 & 22 & 33 \\
Foreign $>95 \%$ & 6 & 1 & 4 & 19 & 30 \\
\hline Total & 56 & 11 & 7 & 312 & 372 \\
\hline
\end{tabular}

Fifty percent of domestic firms conducting export is firm producing crude palm oil (CPO). Meanwhile for foreign firms, 65 percent of the exporting firms also produced crude palm oil (CPO). Indonesia is the largest producer of crude palm oil, therefore not surprising that this sector contribute to the country's export.

Statistical descriptions of the variables used can be seen in Table 2. The table shows that the data used is heterogeneous. On average, firms in the edible oil, vegetable and animal fats industry export 8.6 percent of the products. Meanwhile, the import propensity of firm is 0.4 percent of the raw materials it uses. The average industrial export propensity is higher than firms, which means that on average 17.9 percent of the output produced by the industry is exported abroad. 
Table 2. Statistical Descriptions

\begin{tabular}{lcccc}
\hline \multicolumn{1}{c}{ Variable } & Average & Minimum & Maximum & $\begin{array}{c}\text { Standard } \\
\text { Deviation }\end{array}$ \\
\hline Export propensity of firm & 0.086 & 0 & 1 & 0.251 \\
Import propensity of firm & 0.004 & 0 & 0.994 & 0.055 \\
Export propensity of industry & 0.179 & 0 & 0.760 & 0.157 \\
Import propensity of industry & 0.000 & 0 & 0.029 & 0.004 \\
Capital intensity (thousand rupiah) & 3256583.509 & 141.8 & 397500740.2 & 28734022.45 \\
Labor intensity & 0.181 & 0 & 0.951 & 0.218 \\
Productivity (thousand rupiah) & 1070206 & 4264.25 & 74956379 & 4400581 \\
Foreign Ownership (\%) & 16.747 & 0 & 100 & 35.294 \\
\hline
\end{tabular}

Table 3 shows the estimation results of the factors that influence the export propensity of firms in the industry. Industrial exports have a positive effect on the export propensity of firm. This is because firms in the edible oil, vegetable and animal fats industry generally export.

Table 3. The Influence of Foreign Capital on the Export Propensity in the Edible Oil Vegetable and Animal Fats Industry

\begin{tabular}{lcc}
\hline & Coefficient & p-value \\
\hline Constant & -3.922 & 0.000 \\
$\log (X / O+1)_{j}$ & 3.347 & 0.000 \\
$\log (E S / E+1)_{i j}$ & 0.470 & 0.002 \\
$\log K / E_{i j}$ & 0.026 & 0.059 \\
$\log P T V_{i j}$ & 0.127 & 0.000 \\
$D_{050}$ & 0.280 & 0.135 \\
$D_{5095}$ & 0.718 & 0.000 \\
$D_{95100}$ & 0.759 & 0.000 \\
Number of sample & & 372 \\
Likelihood function & & -2171.72 \\
$H_{0}:$ coefficient $D_{050}=$ coefficient $D_{5095}$ & & - \\
$H_{0}:$ coefficient $D_{050}=$ coefficient $D_{95100}$ & & - \\
$H_{0}:$ coefficient $D_{5095}=$ coefficient $D_{95100}$ & & \\
\hline
\end{tabular}

The industry requires skilled labor to produce. Firms have an average skilled workforce of 18.1 percent of their workforce. Skilled labor has a positive effect on the export propensity of firms. The more skilled workers, the greater export propensity of firms. This result is different from that stated Ramstetter (1999) who found that skilled 
labor had a negative effect on the export propensity of firms in the manufacturing industry in Indonesia. These results support the result of Nauly et al. (2020) that in 2015, firms in the processed food industry no longer rely on cheap labor. A skilled workforce is needed to produce quality products.

Apart from skilled labor, capital intensity also has a positive effect on the export propensity of firms. This research shows that the edible oil, vegetable and animal fats industry requires a lot of capital. The greater the capital a firm has, the greater its propensity to export. These results support the result of Nauly et al. (2020), Kokko et al. (2001) and Athukorala et al. (1995). However, these results contradict the research of Amornkitvikai et al. (2012), Jongwanich \& Kohpaiboon, (2008) and Ramstetter (1999) which show that capital intensity has a negative effect on export trends.

The productivity of the firm has a positive effect on the firm's export propensity. This is in line with the results of Nauly et al. (2020). Firms that have high productivity will have low production costs. The company will have higher competitiveness, thereby increasing the company's tendency to export. This is because the more output is produced per input unit, the lower the cost required to produce one unit of output and eventually will lower the price. Low prices will increase product competitiveness. Thus, high productivity will increase the firm's export propensity.

Foreign ownership also affects the export propensity of firms. The results indicate that coefficients on $\mathrm{D}_{050}$ were not significant. It suggest that firms with foreign ownership share less than 50 percent have the same export propensity as domestic firms. This occurs because firms with minority foreign capital have the same goals as domestic firms, namely to meet domestic needs. For $\mathrm{D}_{5095}$ and $\mathrm{D}_{95100}$ were significant and greater than $\mathrm{D}_{050}$. The export propensity is higher for firms with foreign ownweship greater than 50 percent. But, statistical tests show the foreign ownership coefficients on $\mathrm{D}_{5095}$ and $\mathrm{D}_{95100}$ was similar. Firms with 50-95 percent foreign capital have similar export propensity with foreign ownership greater than 95 percent. This result is different from previous research conducted by Ramstetter (1999) and Nauly et al. (2020). Both concluded that the greater the foreign ownership in the firm, the higher the tendency for its exports to be. This difference can occur because companies with majority foreign ownership (> 50\%) have an export orientation. In addition, there are no differences in technology, managerial know-how and distribution networks in firms with foreign ownership of 50-95 percent with those greater than 95 percent.

Table 4 shows the impact of foreign ownership share on the import propensity of firms in the industry. The import propensity of the industry is influenced by the industrial import propensity. Higher industrial imports make firms tend to import more. This research also proves that skilled labor, capital intensity and productivity, apart from having a positive effect on firm export, also have a positive effect on firm import. Therefore an increase in skilled labor, capital intensity and productivity will not only increase export but also import. 
Table 4. The Impact of Foreign Ownership Shares on the Import Propensity in the Edible Oil Vegetable and Animal Fats Industry

\begin{tabular}{lcc}
\hline & Coefficient & $p$-value \\
\hline Constant & -1.728 & 0.000 \\
$\log (M / R+1)_{j}$ & 40.815 & 0.000 \\
$\log (E S / E+1)_{i j}$ & 0.499 & 0.000 \\
$\log K / E_{i j}$ & 0.052 & 0.000 \\
$\log P T V_{i j}$ & 0.018 & 0.093 \\
$D_{050}$ & - & \\
$D_{5095}$ & -0.629 & 0.000 \\
$D_{95100}$ & 0.203 & 0.000 \\
Number of samples & & 372 \\
Likelihood function & -321.28 & \\
$H_{0}:$ coefficient $D_{050}=$ coefficient $D_{5095}$ & - & \\
$H_{0}:$ coefficient $D_{050}=$ coefficient $D_{95100}$ & - & \\
$H_{0}:$ coefficient $D_{5095}=$ coefficient $D_{95100}$ & & \\
\hline
\end{tabular}

The dummy variable coefficient shows that firms with foreign ownership share between 50 and 95 percent have a lower import propensity than domestic firms. However, if foreign ownership is greater than 95 percent, the import propensity is greater than domestic firms. This can occur because in firms with 50-95 percent foreign ownership, the power of domestic capital owners is still large so they can determine the decisions taken, one of which is related to raw materials. The raw materials used can be obtained from domestically through partnership programs. In contrast to firms that are almost wholly foreign owned, it is difficult for these firms to obtain information on domestic raw material sources. These firms prefer to import from its global network. These results support the research conducted by Nauly et al. (2020) who conducted research on the food industry in Indonesia. In addition, in this industry many firms are vertically integrated especially in the palm oil industry.

The research above reveals that companies that have foreign capital in the edible oil, vegetable and animal fats industry tend to export and import. Companies with majority foreign ownership have a tendency to export, but there is no difference between companies with 50-95\% foreign ownership and above 95\%. The smallest import trend occurs in foreign companies with foreign ownership between 50-95 percent. Based on these results, the government should continue to restrict foreign ownership in the edible oil, vegetable and animal fats industry in Indonesia at the maximum of 95 percent. The effect of foreign ownership share is similar between more than 95 percent or less than 95 percent as long as the forign ownership is still the majority. On the other hand, foreign ownership share more than 95 percent tend to increase import therefore limiting foreign ownership share to a maximum of 95 percent will reduce raw material import. 
In addition, increasing capital will increase export propensity. This is the main reason for the government to keep trying to attract foreign investors which brings capital.

\section{CONCLUSION}

Firms with majority foreign ownership have export propensity, but there is no difference between firms with 50-95 percent foreign ownership and above 95 percent. The smallest import propensity occurs in foreign firms with foreign ownership between 50-95 percent. The government should continue to restrict foreign ownership in the edible oil, vegetable and animal fats industry in Indonesia. Limiting foreign ownership share to a maximum of 95 percent will increase export, on the other hand will decrease import. Efforts to increase exports to firms in the edible oil, vegetable and animal fats industry can be done by increasing capital, skilled labor and firm productivity through foreign direct investment.

\section{REFERENCES}

Amornkitvikai, Y., Harvie, C., \& Charoenrat, T. (2012). Factors Affecting The Export Participation and Performance of Thai Manufacturing Small and Medium Sized Enterprises (SMEs). 57th International Council for Small Business World Conference, pp. 1-35. Wellington, New Zealand: International Council for Small Business.

Athukorala, P., Jayasuriya, S., \& Oczkowski, E. (1995). Multinational Firms and Export Performance in Developing Countries: Some Analytical Issues and New Empirical Evidence. Journal of Development Economics, 46(1), 109-122. https://doi. org/10.1016/0304-3878(94)00050-M.

Belitz, H., \& Mölders, F. (2016). International Knowledge Spillovers Through HighTech Imports and R\&D of Foreign-Owned Firms. Journal of International Trade and Economic Development, 25(4), 590-613. https://doi.org/10.1080/09638199.20 15.1106575 .

Blomström, M., \& Sjöholm, F. (1999). Technology Transfer and Spillovers: Does Local Participation with Multinationals Matter? European Economic Review, 43(4-6), 915-923. https://doi.org/10.1016/S0014-2921(98)00104-4.

Boddin, D., Raff, H., \& Trofimenko, N. (2017). Foreign Ownership and The Export and Import Propensities of Developing-Country Firms. World Economy, 1(21). https:// doi.org/10.1111/twec. 12547 .

Bykova, A., \& Lopez-Iturriaga, F. (2018). Exports-Performance Relationship in Russian Manufacturing Companies: Does Foreign Ownership Play an Enhancing Role? Baltic Journal of Management, 13(1), 20-40. https://doi.org/10.1108/BJM-04-2017-0103.

Charoenrat, T., \& Amornkitvikai, Y. (2021). Factors Affecting the Export Intensity of Chinese Manufacturing Firms. Global Business Review. In-Press. https://doi. org/10.1177/09721509211000207.

Cho, J. (2018). Knowledge Transfer to Foreign Affiliates of Multinationals Through 
Expatriation. Journal of International Economics, 113, 106-117. https://doi.org/10.1016/j. jinteco.2018.04.006.

Dueñas-Caparas, T. (2006). Determinants of Export Performance in the Philippine Manufacturing Sector. Working Paper Discussion Paper Series 2006-18. Philippine Institute for Development Studies (PIDS).

Golikova, V., \& Kuznetsov, B. (2016). The Role of Innovation and Globalization Strategies in Post-Crisis Recovery. SSRN Electronic Journal. https://doi.org/10.2139/ ssrn.2722482.

Hasni, (2018). Dayasaing Ekspor Produk Makanan Olahan Indonesia Ke Timur Tengah. Buletin Ilmiah Litbang Perdagangan, 12(2), 235-265. https://doi.org/10.30908/bilp. v12i2.325.

Hill, H. (1990a). Indonesia's Industrial Transformation Part I. Bulletin of Indonesian Economic Studies, 26(2), 79-120. https://doi.org/10.1080/00074919012331335805.

Hill, H. (1990b). Indonesia's Industrial Transformation Part II. Bulletin of Indonesian Economic Studies, 26(3), 75-109. https://doi.org/10.1080/00074919012331335865.

Jongwanich, J., \& Kohpaiboon, A. (2008). Export Performance, Foreign Ownership, and Trade Policy Regime: Evidence from Thai Manufacturing. ADB Economics Working Paper Series No 140. Manila, Philippines: Asian Development Bank.

Kim, M., \& Choi, M. J. (2019). R\&D Spillover Effects on Firms' Export Behavior: Evidence from South Korea. Applied Economics, 51(28), 3066-3080. https://doi.or g/10.1080/00036846.2018.1564120.

Kim, S., \& Park, D. (2011). Ownership Structure and Export Performance: Firm-Level Evidence from The Republic of Korea. ADB Economics Working Paper Series No. 295. https://doi.org/10.2139/ssrn.2008554.

Kokko, A., Zejan, M., \& Tansini, R. (2001). Trade Regimes and Spillover Effects of FDI: Evidence from Uruguay. Weltwirtschaftliches Archiv, 137, 124-149. https:// doi.org/10.1007/BF02707603.

Mijiyawa, A. G. (2016). Does Foreign Direct Investment Promote Exports? Evidence from African Countries. World Economy, 40(9), 1934-1957. https://doi.org/10.1111/ twec. 12465.

Miravitlles, P., Mora, T., \& Achcaoucaou, F. (2018). Corporate Financial Structure and Firm's Decision to Export. Management Decision, 56(7), 1526-1540. https://doi. org/10.1108/MD-08-2017-0788.

Nauly, D., Harianto, Hartoyo, S., \& Novianti, T. (2020). Foreign Ownership and Export-Import Propensity of the Indonesian Processed Food Industry. Buletin Ilmiah Litbang Perdagangan, 14(1), 47-74. https://doi.org/https://doi.org/10.30908/bilp. v14i 1.431

Radicic, D., \& Djalilov, K. (2019). The Impact of Technological and Non-technological Innovations on Export Intensity in SMEs. Journal of Small Business and Enterprise Development, 26(4), 612-638. https://doi.org/10.1108/JSBED-08-2018-0259 
Ramstetter, E. D. (1999). Trade Propensities and Foreign Ownership Shares in Indonesian Manufacturing. Bulletin of Indonesian Economic Studies, 35(2), 43-66. https://doi. org/10.1080/00074919912331337587

Ramstetter, E. D. (2018). Foreign Ownership and Exports of Thai Manufacturing Plants by Industry in 1996. Asian Growth Research Institute.

Ramstetter, E. D., \& Nguyen, K. (2016). Multinational Enterprises and Vietnam's Exports: Comparing Economy-wide and Firm-level Evidence. AGI Working Paper Series 201622. Asian Growth Research Institute.

Revindo, M. D., Gan, C., \& Massie, N. W. G. (2019). Factors Affecting Propensity to Export: The Case of Indonesian SMEs. Gadjah Mada International Journal of Business, 21(3), 263-288. https://doi.org/10.22146/gamaijb.41022.

Rifin, A. (2017). Determinants of Exporting Firm in Indonesian Food Processing Sector. International Research Journal of Business Studies, 10(1), 15-21. https://doi. org/10.21632/irjbs.10.1.15-21.

Roberts, M. J., \& Tybout, J. R. (1997). The Decision to Export in Colombia: An Empirical Model of Entry with Sunk Costs. American Economic Review, 87(5), 545-564. https://doi.org/10.2307/2951363.

Roper, S., \& Love, J. (2002). The Determinants of Export Performance Panel Data Evidence from Irish Manufacturing Plant (RP02024 ed.). Aston Business School Research Institute. Birmingham, UK.

Safitriani, S. (2014). Perdagangan Internasional dan Foreign Direct Investment di Indonesia. Buletin Ilmiah Litbang Perdagangan, 8(1), 93-116. https://doi.org/10.30908/bilp. v8i1.89

Sjöholm, F. (2003). Which Indonesian Firms Export? The Importance of Foreign Networks. Papers in Regional Science, 82, 333-350. https://doi.org/10.1007/s10110-003-0163-1

Stephanie, H., Tinaprilla, N., \& Rifin, A. (2018). Efficiency of Palm Oil Mills in Indonesia. Jurnal Agribisnis Indonesia, 6(1), 13-22.

Takii, S. (2004). Productivity Differentials between Local and Foreign Plants in Indonesian Manufacturing, 1995. World Development, 32(11), 1957-1969. https:// doi.org/10.1016/j.worlddev.2004.06.010.

Takii, S. (2005). Productivity Spillovers and Characteristics of Foreign Multinational Plants in Indonesian Manufacturing 1990-1995. Journal of Development Economics, 76, 521-542. https://doi.org/10.1016/j.jdeveco.2004.01.006.

Takii, S., \& Ramstetter, E. D. (2005). Multinational Presence and Labour Productivity Differentials in Indonesian Manufacturing, 1975-2001. Bulletin of Indonesian Economic Studies, 41(2), 221-242. https://doi.org/10.1080/00074910500117040. 